\title{
Cytokeratins (CK7 and CK20) Genes Expression Association with Clinicopathological Indices in Oral Squamous Cell Carcinoma and Dysplastic Oral Epithelium
}

\author{
Mehdi Shahabinejad ${ }^{1,2}$, Reza Zare*2, \\ Farnaz Mohajertehran*1,2, ${ }^{\text {, Atefeh Amouzad Mahdiraji }}{ }^{3}$
}

\begin{abstract}
Background: High prevalence of oral squamous cell carcinoma (OSCC) demands the additional novel biological markers. Due to the established roles of cytokeratin in the prognosis of metastasis evaluation the relation of expression of both $C K 7$ and $C K 20$ in OSCC compared to the dysplastic oral epithelium biopsies with clinicopathological factors were investigated.

Methods: We examined the coordinate mRNA expression of cytokeratin 7 (CK7) and cytokeratin 20 (CK20) using quantitative reverse transcription polymerase chain reaction (qRT-PCR) in 110 biopsies of oral squamous epithelium samples including 72 tumoral and 38 dysplastic biopsies. We also collected demographic and pathological data including tumor stage and grade from our patients.

Results: There was a significant difference in $C K 7$ and $C K 20$ gene expression between OSCC and dysplastic samples $(\mathrm{p}<0.001)$. Further, their mean expression in OSCC samples was significantly higher compared to dysplastic samples. Relative mRNA levels of $C K 7$ and $C K 20$ showed that their mean expression in OSCC grade I was significantly lower than other grades $(\mathrm{p}<0.01)$. The relationship between $C K 7$ and $C K 20$ mRNA expression and age or gender was not significant (p> 0.05). Samples in the advanced stage of disease had significantly higher $C K 7$ and CK20 expression compared to early-stage samples of OSCC specimens $(\mathrm{p}=0.001)$.

Conclusions: We found an increase in $C K 7$ and $C K 20 \mathrm{mRNA}$ levels in grade III OSCC samples compared to other grades. This finding suggests a potential role for $C K 7$ and $C K 20$ in oral mucosal carcinogenesis and OSCC prognosis.
\end{abstract}

Keywords: CK20, CK7, Clinicopathological Indices, Cytokeratin, Gene expression, Oral Epithelial Dysplasia, Oral Squamous Cell Carcinoma.

\section{Introduction}

Oral squamous cell carcinoma (OSCC) accounts for over $90 \%$ of oral neoplasms and is considered the world's top eight cancers in terms of incidence (1). The high mortality seen in cases associated with OSCC could be attributed to systemic metastasis and local annual recurrence (2). Most oropharyngeal tumors, considered OSCC, arise from previous lesions called oral dysplastic tissues that have the potential to induce malignant disorders $(3,4)$. 
The categorization of OSCC patients depending on the prognosis and the pathological findings are indications of therapeutic modalities. Efficacies of new modalities in cancer therapies with the preference of surgical resections have been proven (5-7). However, despite the advances in predictive values from OSCC therapies, additional novel biological markers may be required.

Cytokeratins (CK) are a group of antigenically structural filaments specific to epithelium that are preserved in metastasis and malignant transformations $(7,8)$. Thus, CK plays an important role in the prognosis of metastasis or malignancies. Previous studies demonstrate that $C K 7$ and $C K 20$ could help to determine the primary site of metastatic carcinomas (9). Other investigations also established the individual role of $C K 7$ and $C K 20$ or their coordinate role $(C K 7+/ C K 20+)$ in various cancers including colorectal, pancreatic, thymic, liver, ovarian, bladder and gastrointestinal adenocarcinomas, bronchoalveolar carcinoma and Merkel cell skin tumors (10).

Some investigations have declared that most squamous cell carcinomas (SCC) exhibit a negative $C K 7$ or $C K 20$ expression profile (11), however, there may be differences in the coordinate expression of $C K 7$ and $C K 20$ in other epithelial tumors (10).

This study aimed to elucidate the difference in co-mRNA expression of $C K 7$ and $C K 20$ between malignant and benign OSCC tumors compared to dysplastic tissues to provide a more accurate diagnostic marker for OSCC tumors.

\section{Materials and Methods Sample Collection}

This retrospective analytical study was conducted on a total of 110 biopsy samples, specifically 72 OSCC tumoral and 38 epithelial dysplastic tissues. Samples were collected from the Pathology Department and Faculty of Dentistry at Mashhad University of Medical Sciences (MUMS) in Iran. Laboratory analyses were completed in the molecular pathology and cytogenetic laboratory within the Faculty of Medicine of MUMS. Patients consent form was signed by all study participants. Demographic information including age, sex and alcohol, smoke and drug consumption were obtained. Related pathology documents of these samples including the degree of tumor grade and stage of tumor based were also collected. Tumor stage was determined using the tumor-nodemetastasis staging system (12), where the grade I and II was considered early, while grade III and VI were considered advanced (12). All fixed samples in $10 \%$ formalin were cut uniformly with a microtome to ensure $5 \mu \mathrm{m}$ thickness and stained with hematoxylin and eosin (H\&E) for histopathological grading. For laboratory analysis, each sample was deparaffinized by Xylene and then transferred to 96\% Ethanol. The Ethics Committee of MUMS approved all experimental procedures prior to the beginning of this study.

\section{RNA extraction and cDNA synthesis}

To extract mRNA from each sample and evaluate the expression of $C K 7$ and $C K 20$, we performed quantitative reverse transcription polymerase chain reaction (qRT-PCR) according to the manufacturer's instructions (High Pure RNA Paraffin Kit, FFPET RNA Tissue; Roche, Germany). A NanoDrop 2000 spectrophotometer (NanoDrop Technologies, Wilmington, Thermo, USA) was used to evaluate the purity of extracted mRNA using an absorbance ratio of $260 \mathrm{~nm} / 280 \mathrm{~nm}$.

Complementary DNA (cDNA) was synthesized using the Thermo Scientific Revert Aid First Strand cDNA Synthesis Kit (Thermo Scientific, USA). The cDNA synthesis protocol included a $20 \mu \mathrm{L}$ reaction containing $5 \mathrm{x}$ Reaction Buffer (4 $\mu \mathrm{L})$, Ribolock RNase inhibitor $(1 \mu \mathrm{L}), 10 \mathrm{mMol}$ dNTP Mix $(2 \mu \mathrm{L})$ and Reverse Transcriptase $(1 \mu \mathrm{L})$ under ABI thermocycler (One Step, USA). Finally, the quality and concentration of cDNA for each sample was checked using a NanoDrop 2000 spectrophotometer.

\section{qRT-PCR Analysis}

We performed qRT-PCR, to evaluate $C K 7$ and CK20 expression, using the SYBR Green master mix kit (Thermos Scientific, Germany) on an 
ABI thermocycler (One Step, USA) with appropriate primers (Table 1). All reactions were run in duplicate in separate wells and contained $20 \mu \mathrm{L}$ mixture, where each reaction contained $0.5 \mu \mathrm{M}$ (10 Pico molar) of forward primer, 0.5 $\mu \mathrm{M}$ (10 Pico molar) of reverse primer, $10 \mu \mathrm{M}$ SYBR Green master mix, $7 \mu \mathrm{M}$ Diethyl pyrocarbonate water, and $2 \mu \mathrm{L}$ of DNA extract (concentration of $4 \mathrm{ng} / \mathrm{ml}$ ). The PCR experiment began with one cycle at $94{ }^{\circ} \mathrm{C}$ for ten seconds (holding process), followed by 40 amplification cycles at $94{ }^{\circ} \mathrm{C}$ for 30 seconds, $60{ }^{\circ} \mathrm{C}$ for 30 seconds, and $72{ }^{\circ} \mathrm{C}$ for 30 seconds. The final amplification occurred at $72{ }^{\circ} \mathrm{C}$ for 30 seconds. We conducted the $\triangle \Delta C T$ method for differential gene expression of $C K 7$ and $C K 20$ and used the Glyceraldehyde-3-Phosphate Dehydrogenase $(G A P D H)$ housekeeping gene as a reference (Figs. 1 and 2) (13).

Table 1. Primers sequence genes

\begin{tabular}{ccl}
\hline \multicolumn{2}{c}{ Gene } & \multicolumn{1}{c}{ Sequence 5'-3' (position) } \\
\hline \multirow{2}{*}{$\boldsymbol{C K} 7$} & Forward & 5'- GTTCCATTTGCAAAGGCTGT- 3' \\
\cline { 2 - 3 } & Reverse & 5'- CAGGTGGTTACCCGAAAGA -3' \\
\hline \multirow{2}{*}{$\boldsymbol{C K 2 0}$} & Forward & 5'- GGAAGTCGATGGCCTACACAA -3' \\
\cline { 2 - 3 } & Reverse & 5'- GGCCTGGAGCAGCATCAA -3' \\
\hline \multirow{2}{*}{$\boldsymbol{G A P D H}$} & Forward & 5'-CCC ATC ACC ATC TTC CAG G-3' \\
\cline { 2 - 3 } & Reverse & 5'-CAT CAC GCC ACA GTT TCC C-3' \\
\hline
\end{tabular}

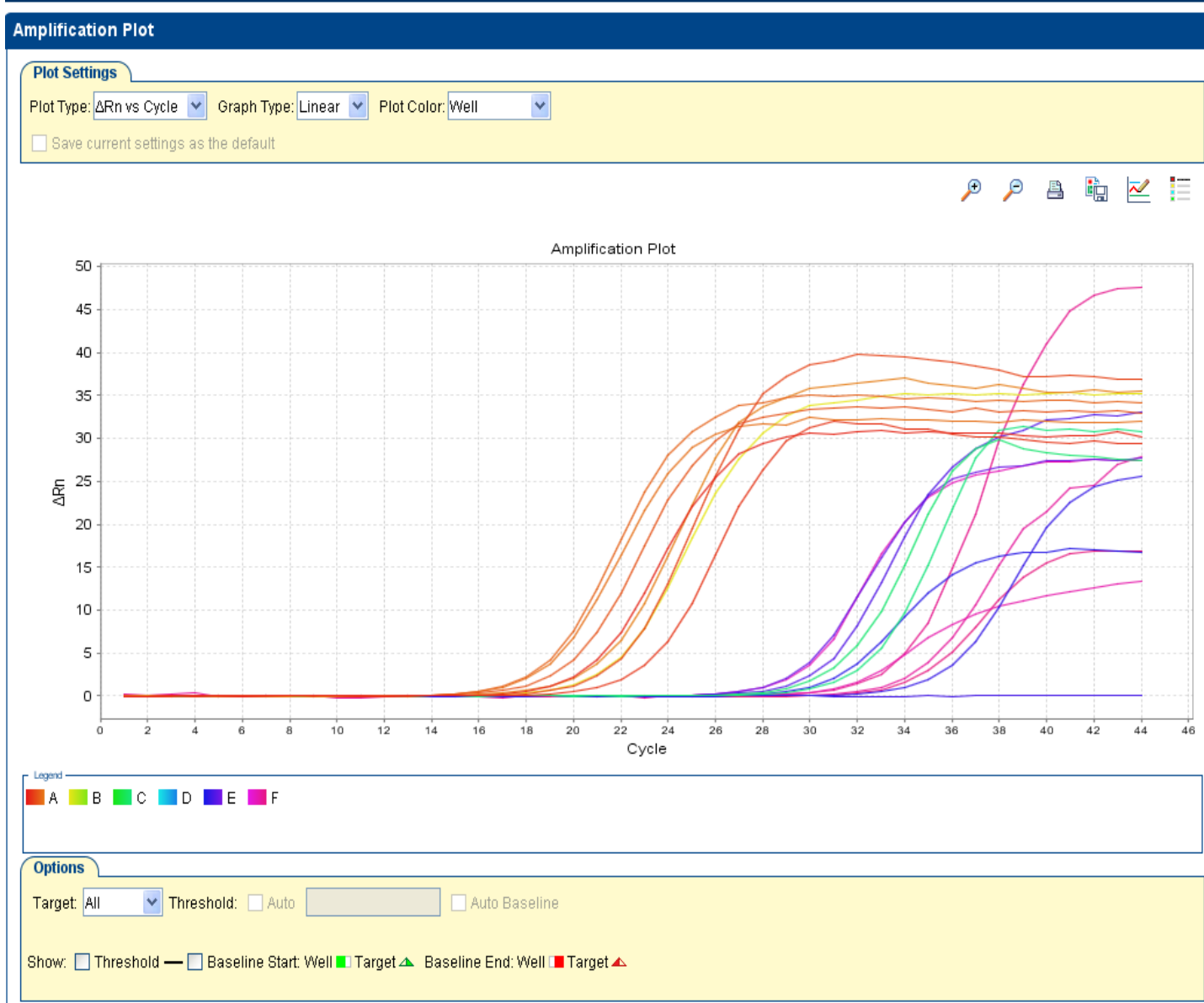

Fig. 1. Amplification plot for $C k 7, C k 20$ and $G A P D H$ expression. 


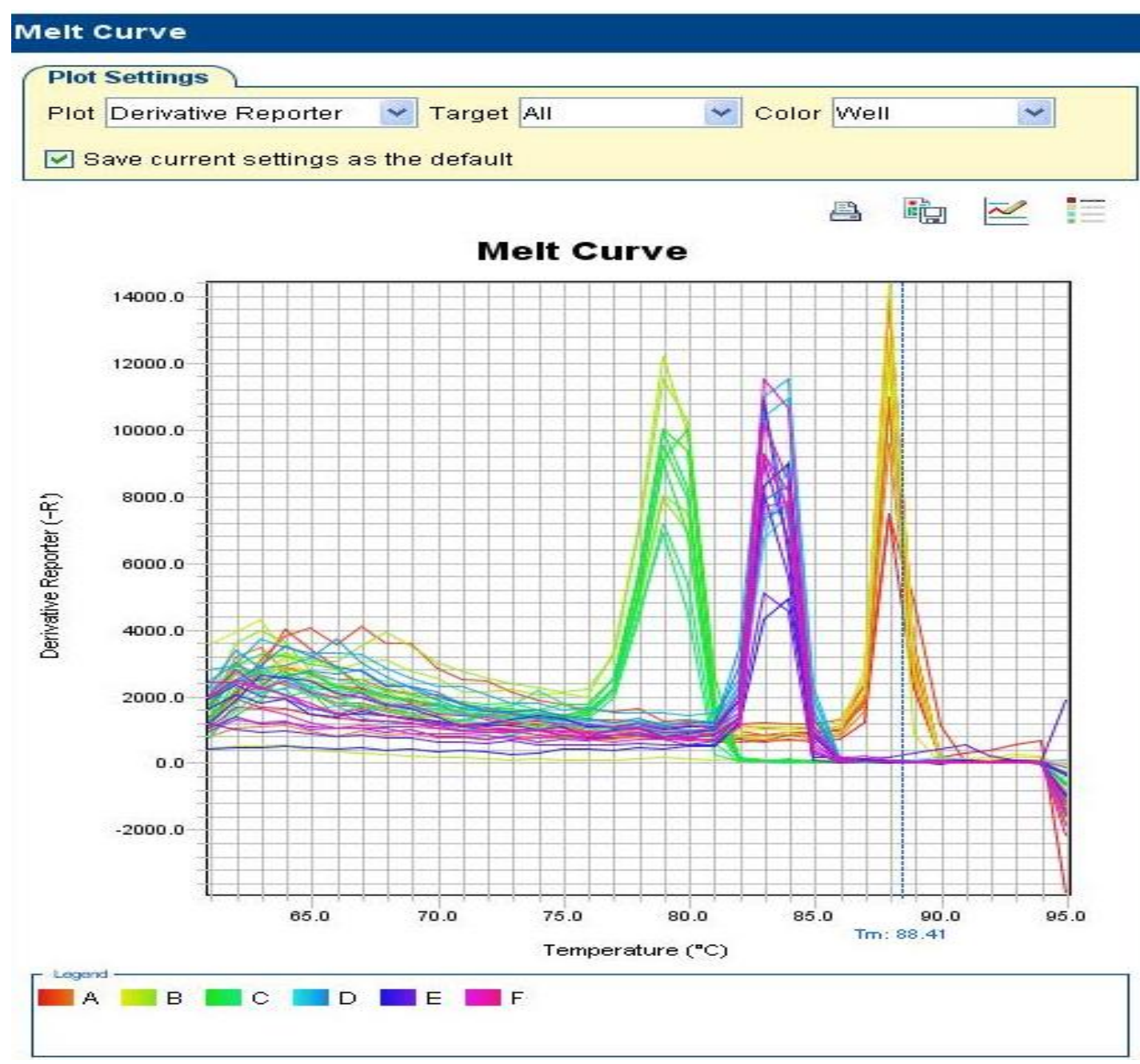

Fig. 2. Melt curve for $C k 7, C k 20, G A P D H$ expression.

\section{Statistical analysis}

We performed statistical analysis using SPSS software version 16 (SPSS Inc., Chicago, IL, USA). Descriptive data including age, sex and mRNA expression were presented as a mean with the standard error of the mean. The normality of data was checked using a oneSample Kolmogorov-Smirnov test. Then, mRNA expressions of the $C K 7$ and $C K 20$ genes were compared to tumoral and dysplastic tissues using an independent samples t-test. Evaluation of $C K 7$ and $C K 20$ expression in tumor and dysplastic tissues and its relationship to clinicopathological parameters including tumor stage and histological grade were assessed using a one-way ANOVA test. A Pearson's correlation coefficient test was used to investigate the correlation between $C K 7$ and CK2O expression levels in tumors and dysplastic tissues and demographic information including age and gender. A p-value of less than 0.05 was considered statistically significant.

\section{Results}

\section{Studied Patients characteristics}

Our experiments included a total of 110 samples, specifically 38 dysplastic samples and 24 samples each of all three OSCC grades (I, II, and III). There were 59 female and 51 male patients with a mean age of $53.48 \pm 15.18$ years. The patient's demographic features that were used to reveal any differences between the OSCC and dysplastic samples were depicted in Table 2. The differences, including age, gender, and consumption of smoke, alcohol, and drugs, were not significant ( $\mathrm{p}>$ $0.05)$. 
Table 2. Demographic features of studied participants.

\begin{tabular}{|c|c|c|c|c|}
\hline Variables & & $\begin{array}{l}\text { Dysplastic group } \\
\text { Number }(\%)\end{array}$ & $\begin{array}{l}\text { OSCC group } \\
\text { Number }(\%)\end{array}$ & p-value \\
\hline Age & $\begin{array}{l}<60 \text { years } \\
>60 \text { years }\end{array}$ & $\begin{array}{l}18(16.33) \\
20(18.18)\end{array}$ & $\begin{array}{l}42(38.18) \\
30(27.27) \\
\end{array}$ & 0.14 \\
\hline Gender & $\begin{array}{l}\text { Female } \\
\text { Male }\end{array}$ & $\begin{array}{l}20(18.18) \\
18(16.33) \\
\end{array}$ & $\begin{array}{l}39(35.45) \\
33(30)\end{array}$ & 0.55 \\
\hline Smoking consumption & $\begin{array}{l}\text { No } \\
\text { Yes }\end{array}$ & $\begin{array}{l}24(21.18) \\
14(12.72) \\
\end{array}$ & $\begin{array}{l}42(38.18) \\
30(27.27) \\
\end{array}$ & 0.17 \\
\hline Alcohol consumption & $\begin{array}{l}\text { No } \\
\text { Yes }\end{array}$ & $\begin{array}{l}23(20.90) \\
15(13.63)\end{array}$ & $\begin{array}{l}49(44.54) \\
23(20.90)\end{array}$ & 0.36 \\
\hline Drug consumption & $\begin{array}{l}\text { No } \\
\text { Yes }\end{array}$ & $\begin{array}{l}18(16.33) \\
20(18.18) \\
\end{array}$ & $\begin{array}{l}40(36.36) \\
32(29.09)\end{array}$ & 0.27 \\
\hline
\end{tabular}

Squamous cell carcinoma of oral cavity (OSCC); p-value was calculated based on chi-square test.

Evaluation of CK7 and CK20 Expression in tumoral and dysplastic mucosa specimens

Table 3 illustrates the differential expression of $C K 7$ and $C K 20$ between dysplastic and OSCC sampled tissues. The results showed that $C K 7$ expression was significantly higher in OSCC tumor tissues than dysplastic mucosa sampled tissues ( $p=0.001$, Table 3). Further, there was a significant difference in $C K 20$ expression between tumor tissues compared to the dysplastic tissues which had a significantly higher expression of CK20 ( $\mathrm{p}=0.001$, Table 3).

Table 3. Expression level of $C K 7$ and $C K 20$ studied genes between two studied groups based on QRT analysis.

\begin{tabular}{cccc}
\hline Variables & $\begin{array}{c}\text { Dysplastic group } \\
\text { Mean } \pm \text { SE }\end{array}$ & $\begin{array}{c}\text { OSCC group } \\
\text { Mean } \pm \text { SE }\end{array}$ & p-value \\
\hline CK7 Expression & $0.33 \pm 0.25$ & $3.75 \pm 1.73$ & $0.001^{*}$ \\
CK20 Expression & $0.47 \pm 0.26$ & $5.12 \pm 2.48$ & $0.001^{*}$ \\
\hline
\end{tabular}

SE; standard error of mean, Squamous cell carcinoma of oral cavity (OSCC); p-value was calculated based on MannWhitney test and*less than 0.05 considered as significant level.

Association of studied cytokine expression (CK7, CK20) with demographic and pathological features

We first examined the correlation between CK7 expression and demographic and histopathological characteristics, including grade and stage of tumors, in tumoral and dysplastic samples (Table 4 and 5). Between both groups, there was no significant difference between $C K 7$ expression and age $(p=0.14)$ or gender $(p=0.55)$. Next, we found that patients with higher OSCC development (grade III) experienced higher $C K 7$ expression than in grade I and grade II patients respectively (Table 5). However, these correlations were not significant between grade I (Spearman's correlation test, $\mathrm{p}=0.18$, $\mathrm{r}=0.36$ ) and grade II patients (Spearman's correlation test, $\mathrm{p}=0.24, \mathrm{r}=0.32$ ). The correlation between $C K 7$ expression and the stage of studied tumors, however, was found to be significant $(p=0.001)$. Patients in the advanced stage of disease had a significantly higher expression of $C K 7$ compared to OSCC patients in the early stages or patients with dysplastic tissue $(\mathrm{p}=0.001)$.

In addition to $C K 7$, we examined the expression of $C K 2 O$ and its correlation to demographic and pathological characteristics in OSCC and dysplastic tissues (Table 4). Between both groups, we found that there was no significant CK20difference between expression and age ( $>>0.05)$ or gender $(p>$ 0.05). However, we found that $C K 20$ 
expression differed significantly among the three OSCC grades $(\mathrm{p}=0.001)$. Patients in grade III experienced a higher CK20 expression than in grade I and grade II patients (Table 5). However, this finding was not significant between grade I and grade II patients $(\mathrm{p}>0.05)$. Our results were significant regarding $C K 20$ expression and the stage of studied tumors $(\mathrm{p}=0.001)$. Lastly, our results showed that patients in the advanced stages of OSCC present significantly higher expression of CK20 compared to OSCC patients in the early stages and patients with dysplastic tissue $(p=0.001)$.

Table 4. Association of expression of $C K 7$ and $C K 20$ genes with age and gender.

\begin{tabular}{|c|c|c|c|c|c|c|}
\hline \multirow{2}{*}{ Gene } & \multirow{2}{*}{\multicolumn{2}{|c|}{ Variables }} & \multirow{2}{*}{$\begin{array}{l}\text { Dysplastic } \\
\text { group } \\
\text { Mean } \pm \text { SE }\end{array}$} & \multicolumn{3}{|c|}{$\begin{array}{c}\text { OSCC group } \\
\text { Mean } \pm \text { SE }\end{array}$} \\
\hline & & & & Grade I & Grade II & Grade III \\
\hline \multirow{3}{*}{ CK7 } & \multicolumn{2}{|c|}{$\begin{array}{l}\text { Age, p-value (Pearson } \\
\text { correlation) }\end{array}$} & $0.66(0.12)$ & $\begin{array}{l}0.93 \\
(0.02)\end{array}$ & $0.15(0.39)$ & $0.96(0.01)$ \\
\hline & Gender & $\begin{array}{l}\text { Female } \\
\text { Male }\end{array}$ & $\begin{array}{l}0.23 \pm 0.15 \\
0.45 \pm 0.29\end{array}$ & $\begin{array}{l}2.68 \pm 0.43 \\
2.62 \pm 0.38\end{array}$ & $\begin{array}{l}2.99 \pm 0.63 \\
2.69 \pm 0.52\end{array}$ & $\begin{array}{l}5.32 \pm 1.32 \\
6.14 \pm 1.72\end{array}$ \\
\hline & p-value & & 0.09 & 0.75 & 0.33 & 0.33 \\
\hline \multirow{3}{*}{ CK20 } & $\begin{array}{l}\text { Age, } p-v \\
\text { correlati }\end{array}$ & Pearson & $0.60(0.14)$ & $\begin{array}{l}0.46 \\
(0.20)\end{array}$ & $0.08(0.46)$ & $0.92(0.02)$ \\
\hline & Gender & $\begin{array}{l}\text { Female } \\
\text { Male }\end{array}$ & $\begin{array}{l}0.44 \pm 0.19 \\
0.50 \pm 0.33\end{array}$ & $\begin{array}{l}4.22 \pm 1.18 \\
3.41 \pm 0.57\end{array}$ & $\begin{array}{l}4.22 \pm 1.47 \\
3.55 \pm 0.88\end{array}$ & $\begin{array}{l}7.07 \pm 3.06 \\
8.16 \pm 2.05\end{array}$ \\
\hline & p-value & & 0.67 & 0.10 & 0.30 & 0.42 \\
\hline
\end{tabular}

* p-value less than 0.05 was considered as significant level. SE; standard error of mean, Squamous cell carcinoma of oral cavity (OSCC).

Table 5. Association of expression of $C K 7$ and $C K 20$ genes between two studied groups with pathological features including grade and stage of disease.

\begin{tabular}{|c|c|c|c|c|}
\hline Gene & Varia & & $\begin{array}{l}\text { Gene expression } \\
\text { Mean } \pm \text { SE }\end{array}$ & p-value \\
\hline \multirow{6}{*}{ CK7 } & \multirow{4}{*}{ Grade } & Dysplastic tissue & $0.33 \pm 0.25$ & \multirow{4}{*}{$0.001^{*}$} \\
\hline & & Grade I & $2.65 \pm 0.39$ & \\
\hline & & Grade II & $2.85 \pm 0.59$ & \\
\hline & & Grade III & $5.76 \pm 0.55$ & \\
\hline & \multirow[b]{2}{*}{ Stage } & Dysplastic tissue & $0.33 \pm 0.25$ & \multirow{2}{*}{$0.001^{*}$} \\
\hline & & $\begin{array}{l}\text { Early stage } \\
\text { Advance stage }\end{array}$ & $\begin{array}{l}2.79 \pm 0.10 \\
4.52 \pm 0.39 \\
\end{array}$ & \\
\hline \multirow{7}{*}{ CK20 } & \multirow{4}{*}{ Grade } & Dysplastic tissue & $0.47 \pm 0.26$ & \multirow{4}{*}{$0.01^{*}$} \\
\hline & & Grade I & $3.79 \pm 0.97$ & \\
\hline & & Grade II & $3.90 \pm 1.24$ & \\
\hline & & Grade III & $7.65 \pm 2.54$ & \\
\hline & \multirow{3}{*}{ Stage } & Dysplastic tissue & $0.33 \pm 0.25$ & \multirow{3}{*}{$0.001^{*}$} \\
\hline & & Early stage & $4.14 \pm 0.24$ & \\
\hline & & Advance stage & $5.88 \pm 0.59$ & \\
\hline
\end{tabular}

* p-value less than 0.05 was considered as significant level. SE; standard error of mean, p-value calculated based on oneway ANOYA test. 


\section{Discussion}

The overexpression of CK, a group of epithelium filaments, was reported amongst different cancers $(7,8)$. Among 20 specified types of CK, the individual expression of $C K 7$ and CK20 or their co-expression was also reported (10). However, their co-expression in salivary glands and OSCC tumor tissue and how it relates to pathologic markers is much less understood $(11,14,15)$. Therefore, further investigation is required to elucidate the diagnostic potential of $C K 7$ and $C K 20$ coexpression in OSCC tumors.

According to previous investigations, salivary gland tumors were assessed for their $C K 7 / 20$ profile. They found that all salivary gland neoplasms had a $C K 7+/ C K 20$ - immune profile while squamous cell carcinomas (SCC) samples showed negative $C K 7 / 20$ expression. The authors conclude that these profiles cannot discriminate between the different types of salivary gland neoplasms or the differences between benign and malignant salivary gland tumors (16). In rare cases of spindle cell squamous cell carcinoma of the tongue, immunohistochemical analysis revealed that tumor cells were positive for some pancytokeratin (17). In the case of a lower left gingival tumor, $C K 7$ expression was found positive in a mixture of SCC and tubular formation. However, $C K 7$ was found to be negatively expressed in their margin tissues (18). There were also reports about the negative expression of CK7 or CK20 in basaloid squamous cell carcinoma (19) and Adenoid squamous cell carcinoma (20, 21). Recently, however, SCC tissues were identified by the positive expression of $C K 7$ in dysplastic and invasive lesions of luminal and basal tissues (6). Chue et al. found that $C K 7$ expression was positive in most carcinoma cases except colon, prostate, kidney and thymus carcinomas, lung carcinoid tumors, gastrointestinal tract and Merkle cell carcinoma (6). $C K 7$ expression was positive in all salivary glands, however, $C K 20$ expression was negative (6). This study aligns with our results with regards to $C K 7$ expression in the salivary gland but differed for CK2O expression. These results could be attributed to a difference in protocol between the studies and the lack of SCC samples in the assay conducted by Chue et al (6).

Abdul-Maksoud et al. evaluated CK20 expression in 80 samples with bladder cancer using qRT-PCR and compared the results to healthy samples (7). They investigated 54 samples of transitional cell tumoral tissue as the invasive group and SCC tissue as the noninvasive group (20). Similar to our study, they found that increased $C K 20$ expression was associated with disease stage and grade. They concluded that the detection of CK20 had a high predictive prognostic value when differentiating between invasive and noninvasive carcinoma. Though their study results were like our findings, we both investigated different $C K 7$ and $C K 20$ genes in OSCC tissues. Lastly, the expression of CK19 and CK2O was investigated to improve bladder cancer screening and diagnosis (22). Morsi et al. found that $C K 19$ and $C K 20$ were the best candidates as they provided the highest sensitivity and specificity (22).

In this current study, we first examined the correlation between the coordinate expression of $C K 7$ and $C K 20$ on the RNA level to different histological grades and stages. We then investigated the presence of non-OSCC specimens in dysplastic specimens and OSCC samples with different histopathological grades. While our study used a large sample size, there were a few limitations including the absence of healthy individuals to measure $C K 7$ and CK20 expression levels, or their expression in adjacent tumors tissues. The association between prognosis, tumorigenicity and survival rate of OSCC patients to the expression of $C K 7$ and $C K 20$ may be of interest for further investigations.

We concluded that the expression of $C K 7$ and $C K 20$ was significantly higher in OSCC tumor samples compared to dysplastic samples. This finding could be due to the amplification role of these two markers during carcinogenic processes of oral mucosa cancers. This significant difference was also found to be related to histopathological grade, where 
patients with higher development in grade III experienced a higher expression level of both $C K 7$ and CK2O in comparison to grade I and grade II patients.

Lastly, mRNA expressions of $C K 7$ and CK2O were significantly higher in advanced stages compared to earlier stages of OSCC tissues. Therefore, measuring the coordinate expression levels of $C K 7$ and $C K 20$ could serve as a potential prognostic biomarker and

\section{References}

1. Shahabinejad M, Asadi Z, Mohajertehran F. LAMP3 (CD208) Expression in Squamous Cell Carcinoma and Epithelial Dysplasia of the Oral Cavity and Clinicopathological Characteristics of Unfavorable Prognosis. Reports of Biochemistry and Molecular Biology. 2021;9 (4):373-378.

2. Geum D-H, Roh Y-C, Yoon S-Y, Kim H-G, Lee J-H, Song J-M, et al. The impact factors on 5-year survival rate in patients operated with oral cancer. J Korean Assoc Oral Maxillofac Surg. 2013;39(5):207-216.

3. Liu SA, Wong YK, Lin JC, Poon CK, Tung $\mathrm{KC}$, Tsai WC. Impact of recurrence interval on survival of oral cavity squamous cell carcinoma patients after local relapse. Otolaryngology-Head and Neck Surgery. 2007;136(1):112-8.

4. Sharma P, Saxena S, Aggarwal P. Trends in the epidemiology of oral squamous cell carcinoma in Western UP: an institutional study. Indian Journal of Dental Research: official publication of Indian Society for Dental Research. 2010;21(3):316-9.

5. Tepper JE, Krasna MJ, Niedzwiecki D, Hollis D, Reed CE, Goldberg R, et al. Phase III trial of trimodality therapy with cisplatin, fluorouracil, radiotherapy, and surgery compared with surgery alone for esophageal cancer: CALGB 9781. Journal of clinical oncology. 2008;26(7):1086-92.

6. Fiorica F, Di Bona D, Schepis F, Licata A, Shahied L, Venturi A, et al. Preoperative chemoradiotherapy for oesophageal cancer: a systematic review and meta-analysis. Gut. 2004;53(7):925-30.

7. Chu P, Wu E, Weiss LM. Cytokeratin 7 and cytokeratin 20 expression in epithelial eoplasms: improve the diagnosis of higher grades of OSCC tumor tissue.

\section{Acknowledgements}

The authors appreciate the Research Council of Mashhad University of Medical Sciences, Faculty of dentistry for their financial support under thesis number 970702.

The authors declare that there are no conflicts of interest.

survey of 435 cases. Modern Pathology. 2000;13(9):962-972.

8. Stopyra GA, Warhol MJ, Multhaupt HA. Cytokeratin 20 immunoreactivity in renal oncocytomas. The Journal of Histochemistry \& Cytochemistry. 2001;49(7):919-920.

9. Chhieng DC, Cangiarella JF, Zakowski MF, Goswami S, Cohen JM, Yee HT. Use of thyroid transcription factor 1, PE-10, and cytokeratins 7 and 20 in discriminating between primary lung carcinomas and metastatic lesions in fine-needle aspiration biopsy specimens. Cancer Cytopathology. 2001;93(5):330-336.

10. Wang N, Zee S, Zarbo R, Bacchi C, Gown A. Coordinate expression of cytokeratins 7 and 20 defines unique subsets of carcinomas. Applied immunohistochemistry. 1995;3(2):99-107.

11. Nikitakis NG, Tosios KI, Papanikolaou VS, Rivera H, Papanicolaou SI, Ioffe OB. Immunohistochemical expression of cytokeratins 7 and 20 in malignant salivary gland tumors. Modern Pathology. 2004;17(4):407-415.

12. Mohajertehran F, Ayatollahi H, Khazaeni K, Shakeri M-T, Mohtasham N. Overexpression of high-mobility motor box 1 in the blood and tissues of patients with head and neck squamous cell carcinoma. Iranian journal of otorhinolaryngology. 2018;30(100):261-271.

13. Mohtasham N, Ayatollahi H, Saghravanian N, Zare R, Shakeri M, Sahebkar A, et al. Evaluation of Tissue and Serum Expression Levels of Lactate Dehydrogenase Isoenzymes in Patients with Head and Neck Squamous Cell Carcinoma. Anti-Cancer Agents in Medicinal Chemistry (Formerly Current Medicinal Chemistry - Anti-Cancer Agents). 2019;19(17). 
14. Weinreb I, Tabanda-Lichauco R, Van der Kwast T, Perez-Ordoñez B. Low-grade intraductal carcinoma of salivary gland: report of 3 cases with marked apocrine differentiation. The American journal of surgical pathology. 2006;30(8):1014-1021.

15. Lee JH, Lee JH, Kim A, Kim I, Chae Ys. Unique expression of MUC3, MUC5AC and cytokeratins in salivary gland carcinomas. Pathology international. 2005;55(7):386-390.

16. Terada T. Adenoid squamous cell carcinoma of the oral cavity. International journal of clinical and experimental pathology. 2012;5(5):442.

17. Silva DFB, Santos HBdP, León JE, Gomes DQdC, Alves PM, Nonaka CFW. Clinicopathological and immunohistochemical analysis of spindle cell squamous cell carcinoma of the tongue: a rare case. Einstein (São Paulo). 2019;17(1).

18. Xie S, Bredell M, Yang H, Shen S, Yang H. Basaloid squamous cell carcinoma of the maxillary gingiva: a case report and review of the literature. Oncology letters. 2014;8(3):1287-1290.
19. Kusafuka K, Ebihara M, Ishiki H, Takizawa Y, Iida Y, Onitsuka T, et al. Primary adenoid squamous cell carcinoma of the oral cavity. Pathology international. 2006;56(2):78-83.

20. Mestre VF, Medeiros-Fonseca B, Estevao D, Casaca F, Silva S, Félix A, et al. HPV16 is sufficient to induce squamous cell carcinoma specifically in the tongue base in transgenic mice. The Journal of Pathology. 2020;251(1):4-11.

21. Abdul-Maksoud RS, Shalaby SM, Elsayed WS, Elkady S. Fibroblast growth factor receptor 1 and cytokeratin 20 expressions and their relation to prognostic variables in bladder cancer. Gene. 2016;591(2):320-326.

22. Morsi MI, Youssef AI, Hassouna ME, ElSedafi AS, Ghazal AA, Zaher ER. Telomerase activity, cytokeratin 20 and cytokeratin 19 in urine cells of bladder cancer patients. Journal of the Egyptian National Cancer Institute. 2006;18(1):82-92. 